\title{
UNDERSTANDING TRANSITION: AN ANALYSIS OF TRANSITION PRACTICES FROM PRESCHOOLS TO PRIMARY SCHOOLS IN MAURITIUS
}

\section{SARASWATEE RAJIAH}

Lecturer, Institution: Mauritius Institute of Education, Mauritius

\begin{abstract}
The purpose of this article is to examine the children's transition from pre-school to primary schools in Mauritius. Transition practices are a widely researched phenomenon, within formal schooling. Much research conducted within the context of children's transition from one setting to another, has focused on both children and parents' viewpoints and very few on the teacher's viewpoint. In this article, transition practices of teachers have been taken into consideration, to understand the transition of children moving from preschool to primary school.

This article begins, by describing the process of transition within different contexts. Using the interpretivist paradigm, interviews have been conducted with teachers, from both preschool and primary schools. The discussion then examines transition practices, from different perspectives. Findings from various studies on transition has been analyzed to convey a better understanding of how to ensure that, the transition from preschool to formal schools is effortless for children. The different perspectives are compared critically, with the aim of understanding the transition of children from preschool to primary schools.

Future directions and questions for research, within the context of children's transition are discussed within this article. This article may be of assistance to readers with a view of understanding the evolution of transition practices and the process of transition of children, when moving from preschool to a primary school setting.
\end{abstract}

KEYWORDS: Formal Schooling, Transition \& Transition Practices

Received: Aug 20, 2017; Accepted: Sep 11, 2017; Published: Oct 13, 2017; Paper Id.: IJESROCT201712

\section{INTRODUCTION}

Preschool education in Mauritius starts, at the age of 3 and ends when the child reaches 5 years old, that is, prior to joining formal schooling. Standard I or Grade I teachers will welcome children aged between 5 and 6 years old, in their receiving classrooms in primary schools. There is no prescribed curriculum, for preschool education. However, all preschool teachers work on different themes, that is, using a thematic approach. For instance, teachers usually start with a theme called 'All about me', which lays more emphasis on knowing oneself, followed by the theme 'Family', 'Means of Transport', 'World of Animals' and so on. Like in all other countries, preschool teachers make learning fun, through areas of learning. In the National Curriculum Framework Pre-Primary, there are six areas of learning, namely, Personal, Social and Emotional Development (PSED), Communication, Language and Literacy (CLL), Mathematical and Logical Thinking (MLT), Expressive, Creative and Aesthetic Development (ECAD), Bodily and Environmental Awareness 
(BEA) and Health and Physical Development (HPD). Each area of learning has its own descriptors and each descriptor has a list of performance indicators. Preschool teachers develop their own activity sheet by mentioning the name of the activity to be done, the aim of doing the activity which is the descriptor, the objective of doing the activity becomes the performance indicator of the chosen descriptor.

Beach's Consequential Transition has been used as the theoretical framework to analyze the transition practices of teachers both at preschool and primary school. According to Beach (1999), transfer assumes what Kindermann and Skinner (1992) have called a launch model of person-environment relations. The launch model implies the initial situation through which a person learns largely determines what the person will do in a new task or situation that, unlike the first, does not alter the course of the individual's learning. It also implies that earlier learning determines the trajectory of later learning because later environmental influence on learning is minimal. It is consistent with transfer as the application of prior products of learning, and with instructional efforts aimed that the creation of general schemes and strategies for transfer.

Pianta and Kraft-Sayre (1999) define the transition period as a process through which children experience a significant change from one environment to another quite different one and in which they will need knowledge, abilities and skills in order to adapt to their new setting. For Mc Cormick, Mullins \& Townley (2005), transitions are an essential part of each child's growing up, particularly in the early years, and the transition to school is part of a lifelong and continuous process, a visible and inevitable marker that children are growing up and their horizons are expanding to meet new people and new challenges. Becoming a school child involves interpreting information and constructing understandings about school and the role of students. The transition can be horizontal, vertical or internal. Vertical transitions are the major changes that take place as a child moves through the early year's system of services towards and including school. Internal transitions occur when a child moves within a setting because of their age or stage, and horizontal transitions are much broader and include those that a child experiences on a day-today basis, concurrently during the week, throughout the day within one setting, and in the natural course of the day. Robinson (2003) wrote:

"Development is all about transitions. All our lives are a series of transitions; conception to birth, birth to toddlerhood, to preschooler, school-age child to adolescent, adolescent to adult, adult to our final transition - when we die. Throughout this time, we have the capacity for change and adaptation, but we all need a starting point. Our universal starting point is when we emerge from our mothers in the world as a bundle of raw, unregulated emotion. From the first moment through our primary experiences of need and response comes the formation of the first feelings of emotional security and safety."

Research on transition has emphasized the differences children experience as they move from preschool to primary school. According to Dunlop (2014), the most dominant of these differences are differences in settings, in relationships and in the curriculum. It has also been highlighted that focus has been made on the need to prepare children for school, to support them in their adjustment to school, and more recently to advocate the need for schools to change their practices to be 'child ready' so that the changes children need to make to accommodate new experiences are better matched by practices in the new school. The age of transition to school varies from country to 
country and the capacity of children to cope with change may develop as they grow older, or in the light of how change has been experienced previously. Dunlop (2014), when discussing about theorizing transition and how methods of study change, evolve, and have an impact on the process of theorizing, also mentioned that certain transitions are educational markers: the entry to the first out of home setting, joining an early childhood group setting, starting school, moving to a new level of the school or into the next school, moving out of one school to another and eventually, leaving school behind.

The transition has been defined in terms of the intensified demands for children (Fthenakis 1998), as well as families (Griebel and Nielsen 2009). Researchers have suggested that these demands present overwhelming challenges for some children (Hirst et al. 2011). Others have focused on the importance of providing support and acknowledging the strengths of children as they go through the challenges and develop an enhanced sense of their own competence (Fabian and Dunlop 2007; Page 2000). There is an on-going debate worldwide about the role of adjustment, adaptation, continuity and readiness in transition to school, the timing of the transition and the teacher and/or school practices that support transition (Broström and Wagner 2003; Dockett and Perry 2013, in press; Dunlop and Fabian 2007; Petriwskyj et al. 2005; Ramey and Ramey 1999; Vrinioti et al. 2010; Yeboah 2002). The outcome of a positive transition is a sense of belonging in the new setting (Dockett and Perry 2004; Fabian 2007).

As stated by Arnold, Bartlett, Gowani and Shallwani (2008), children's transition to school presents a critical time and unique opportunity to lay the groundwork for their long term academic and social success. The authors explained that there are many factors which are critical to improving transition process, and these are

- A need for data, for information in particular, on common indicators that can be used to ascertain the situation at a very broad level.

- There is a need to gather research evidence and draw out best practices from programs around the world which successfully enhance children's readiness for school, school's readiness for children, and the transition process.

The authors emphasized that ECD programs aim at providing holistic curriculum, active learning, and rich, stimulating environments, whereas Grade I classrooms often reflect the more formal and routine nature of primary school. It was also noted that there have been a number of efforts to improve the transition experience for young children moving from ECD programs or home to early primary, both in terms of specific transition activities and in terms of integrating ECD and early primary school in certain ways.

Across the world, transitional activities have been initiated by ECD programs to alleviate the often dramatic, change that children experience when they shift from the early childhood settings to Grade I. Bartlett et al. (2003) explained about Save the Children transition program which was introduced in Nepal for those children who are in their last year in the ECD settings. In the program, children were introduced to some activities and skills that would be essential when they enter primary schools. The program also arranged for children to visit the primary schools and ensured that Grade I teachers visited children in the ECD settings. Teachers in the primary schools were also concerned as they learnt to develop commitment to children's rights, with particular emphasis on providing a 
welcoming and non-punitive atmosphere for all children, especially girls and those children from marginalized groups, and on the use of active learning approaches. Bartlett et al. (2004) noted that this particular transition program showed significant improvements in school attendance, pass rates, and promotions, and corresponding reductions in dropout and repetition.

In Guyana, Rodrigues (2000) conducted a research project which brought preschool teachers, Grade I teachers and parents together, to discuss the transition problems of children and the disconnects between ECD and the formal system, which was resulting in higher Grade I dropout rates. The aim of the research project led both groups of teachers to agree on goals for children, including the basic skills and cognitive development, socialization for respect, and the extension of learning outside the classroom. In this project, preschool teacher and Grade I teachers were paired and worked together, resulting in home visits, smaller group work, and setting up of learning corners and activities in the Grade I that were more suitable to the learning styles of young children.

Arnold et al. (2008) found that transition issues must be given greater attention if children's overall development and learning are to receive better supports. The authors recommended actions on better links, coordination, cooperation, and understanding between ECD programs and the primary school system, and prioritization of attention to and resources for the early grades of primary school as a central component of education reform, among others. These two recommendations are in line with what this study is currently trying to find.

Transition practices are the strategies that are used to smooth transition from one setting to another. When moving from preschool to primary school, preschool teachers prepare children, focusing on the areas of learning. When the child joins, primary school, the primary school teacher who has a prescribed curriculum welcomes the child with a certain goal to achieve by the end of each semester. O'Connor (2013) has mentioned that supportive environments make a difference to transition and elaborated on different aspects of how reception class teachers, friends, and emotions can influence transition of a child.

Transition from preschool to Foundation year I or formal schooling has been recognized as an important developmental milestone in the lives of children and it has been seen to impact directly on later academic achievements and outcomes (Mascareño, 2014; Suzuki, 2013; Rimm-Kauffman \& Pianta, 2000; Rosenkoetter, Schroeder, Rous, Hains, Shaw \& McCormick, 2009; Schulting, Malone \& Dodge, 2005). The process of transition has been studied worldwide, internationally and has been a focus of research that has considered a large number of variables involved that led to contributions to the topic. The transition has been understood through the ecologies in which development of the child takes place and family experiences, and can be also understood through children's early experiences (Dockett \& Perry, 2007). Whatever children experience at preschool, shape their behavior which will definitely have an effect as they enter a new phase, the formal schooling.

In accordance with Copple and Bredekamp (2009), Koizumi (2000) stated that changes are very significant in the early years for children. This may be because children have not yet attained that level of maturity that allows them to adapt to different circumstances or contexts. Dodge, Colker and Heroman (2001) argued that, for children, adults who spend most of their time with them, satisfying their basic needs, namely, biological, social, emotional 
and so on, become the most significant persons along the lives of the children, and thus they have the potential to help them during their transition. Schulting et al. (2005) pointed out that, going from preschool to primary school represents a very challenging period for children because of the number of variables involved and the ways in which they can negatively impact on them. Pianta (2002) argued that, the transition to a more structured classroom setting and with more peers is likely to trigger anxiety in children. In the same vein, Li, Mak, Chan, Chu, YMak Lee and Lam (2013) emphasized that, larger class size, a subject based curriculum, stricter school rules, more homework, a tighter timetable and longer school hours which demand the use of literacy and numeracy skills are what make the transition from preschool to primary school challenging. Mascareño (2014) pointed out that, children enter a world of higher expectations, where academic demands represent one of their main challenges, comprising a more structured learning environment, more teacher-directed activity and academic assessments.

Dockett and Perry (2007) pointed out that, the transition period from preschool to primary school may represent a great challenge because of adults' perceptions, expectations and different conception with regard to what children need to start primary schooling. Simultaneously, Fabian and Dunlop (2005) also pointed out that changing relationships, environment, rules and even teaching styles may place strong demands on children and families.

Some studies have shown that early interventions are strongly associated to children's future lives in a positive way, and suggested the need to promote a smooth transition. Findings from an analysis of the effect of the implementation of transition activities in 992 schools with data from a national longitudinal study in the U. S. By Schulting, Malone and Dodge (2005), showed that schools, which implemented more transition activities (e.g., information sessions for parents, open houses, visits to the primary school) showed better academic scores at the end of the year. McCubbins (2004) highlighted the potential of implementing transition activities in schools and its influence on personal development of the child throughout his life and also emphasized the importance of helping children, develop social and emotional skills. Since, personal development has been mentioned; LoCasale, Mashburn, Downer and Pianta (2008) found that, transition activities that were implemented in preschools, primary school teachers reported fewer problem behaviors and more positive social competence. Other authors have argued that social skills play a major role in smoothing the transition into primary school, which can be improved by positive and appropriate teacher-child and parent-child relationship (Claes, 2010; Pianta \& Stuhlman, 2004).

The findings of a longitudinal study which examined the associations between teacher-child interactions and children's achievement in primary school settings in the USA revealed that more emotional support offered by teachers at primary school led to more phonological awareness. In Finland, Ahtola, Silinskas, Poikonen, Kontoniemi, Niemi and Nurmi (2011) carried out a study, which assessed the transition practices of preschool and primary school teachers, and the extent to which, the use of these practices contributed to the academic development of children. Children were assessed in different areas, such as reading, writing and mathematical skills. The findings suggested that aligning the curricular and sharing written information between preschool and primary school were the best predictors for a positive children's skills development. Further, the more diversity of transition practices implement, predicted specifically a major development on the academic skills of children.

Cassidy (2005) explored the perceptions, attitudes and expectations of primary school teachers with regard 
to the transition period in Scotland. A group discussion consisting of 6 first grade teachers was videotaped and the teachers were interviewed. The teachers were very much concerned about the ability of children to adjust to the primary school, they mentioned about visiting a preschool setting which can prove to be very beneficial and the knowledge that children bring from preschools was vital to ensure their transition to be a smooth one. Similarly, Hanson et al. (2000) found that families perceive the transition as an event than as a process. The authors also reported that families perceive the transition period as moving from a known situation to the unknown one, and therefore showing a certain level of anxiety.

Lately the focus has been on the need to prepare children for school, to support them in their adjustment to school and more recently, to advocate the need for schools to change their practices to be 'child ready' so that the changes children need to make to accommodate new experiences are better matched by practices in the new school (Margetts \& Kienig, 2013). Fabian (2002), pointed out that, some preschools prepare children for school by giving them worksheets and formal lessons. However, Nutbrown (1994) argued that, well-meaning educators can waste time and insult the intellect of young children by requiring them to do things that they will need to do when they go to school.

The 'Building Bridges' study of O'Kane (2007a, 2009); found that there is a lack of communication between preschool and primary schools in Ireland. The study of O'Kane investigated the beliefs of both preschool and primary school practitioners about the process of transition, and examined transition from the perspective of children undergoing the transition and their parents. The study findings reported that the beliefs, expectations and classroom practices of both preschool and primary school teachers have a great impact on transition. Kienig (2013) suggested that there should be more detailed studies that examine that functioning of 6 year olds at school and create a platform for cooperation for all those interested in an auspicious start at school for children: the parents, the teachers and the researchers. Since the transition of children moving from preschool to primary school involves their coping or adjustment in new settings, Broström (2002) and Dunlop (2002) noted that, coping of children at school is supported when there is communication between all the people and cooperation between schools and kindergartens in sharing information about children and building curricular continuity and co-constructing transition activities. There are challenges involved in transition. Fabian (2013) pointed out that the challenge for educators involve understanding the range of expectations and perspectives of others, including children, to achieve curriculum continuity and socio-emotional well-being in the new setting. Brooker (2008) added that, educators need to see the transition as schools and settings working together to mediate any discontinuities, rather in terms of 'readiness' or 'adjustment'. Successful transition result in a child who feels strong, competent, and able to handle new experiences with confident. Children moving from preschool to primary school need to adjust and adapt themselves to new classroom settings. Most research on the transition from preschool to primary school has focused on children and families.

Kotaman (2009) reported that, although children gained some skills for first grade in preschool classrooms, it would not be easy to adapt to less child-centered and more structured first grade classrooms, after the preschool classroom in which, the activities and relationships between child and teacher are more flexible. 
The transition has mostly been studied through children's perspectives, parents' perspectives and families. There have been quite a number of investigations which studied the role that teachers play in the transition period. Studies have focused on the attitudes, perceptions, experiences, knowledge, interactions, and the use of transition practices that would ease transition of children. Pianta, Cox, Taylor and Early (1999) found that the most common and frequent transition practices carried out by primary school teachers were to send flyers to families of children create brochures and organize open houses. Later, LaParo, Pianta and Cox (2000) found that among the transition practices of preschool teachers were sending a letter to families of children and holding open houses. The authors also found that most primary teachers reported that the most common transition practice was classroom visits by kindergarten children. Literature has reported that the use of transition practices is one of the ways to help smooth transition of children.

Studies on transition have reported that the problems that teachers encountered with children who join formal schooling for the first time are difficulty following instructions, working independently and lack of academic skills. Rimm-Kauffman, Pianta and Cox (2000) have used data from a national survey and explored teachers' judgments to identify the prevalence and types of problems, they face during transition in the US, and found the problems as mentioned. Other studies have shown that, these problems are actually factors of school readiness. Many studies have found that, in order for children to undergo a smooth transition, the children need to be ready. At the same time, the primary schools as well need to be ready. Several authors mentioned about 'Ready Children' and 'Ready Schools', when speaking of smooth transition, with regard to school readiness. The question which researchers need to ask as per Nielsen and Griebel in Dunlop and Fabian (2007:25) is, 'Is the school ready for the child?' As per the UNICEF United Nations Children's Fund, (2012), in its conceptual framework for school readiness, defined school readiness in terms of two features and three dimensions, the two features being 'transition' and 'gaining competencies' and the three dimensions which are Ready Children, Ready Schools and Ready Families.

Griebel and Nielsen (2000) found that, children only had a vague idea about what to expect, were nervous and insecure, but were convinced that they were going to do well at school. According to Fabian (1998), the things that children look forward to include: "being big", having an approachable teacher, choosing from a wider variety of activities, making new friends, although some children worry that, they might not know anyone at first.

Brooker (2008) pointed out that, government policy makers tend to view children's transitions purely, in terms of school readiness. She commented on how "transition strategies have concentrated on the concept of readiness, generally in the traditional sense of the 'readiness for school' of each individual child. The burden of responsibility for a successful transition in this view lies with the child and with those adults, whose task it is to prepare her or him for 'stepping up' the educational ladder. Successful transitions, in this account, are achieved by individuals who have acquired the requisite academic knowledge and social skills to perform, conform and learn in the new setting. This perspective, which tends to blame those children, families and communities who have not achieved readiness, was exemplified in the first of the US National Educational Goals ("by the year 2000 all children in America will start school ready to learn'; National Educational Goals Panel 1991) although it has been repeatedly 
critiqued by researchers.

Most research on transition has been linked to school readiness. Helping preschoolers get ready to enter Grade I and make satisfactory progress during the early years of formal schooling is considered as a challenge. Ladd (2005) mentioned that to understand how young children are best prepared to enter and succeed in grade school has become a priority among parents, educators, legislators and researchers. He also explained that the definition of school readiness as provided by practitioners and policy makers says that, by the time children join grade school, they have reached a certain level in their development that makes them adapt to the challenges of formal schooling. However, it has also been noted that every year, there are large numbers of children who have difficulty adapting to grade school. While Love and Raikes described the qualities of young children's development that, explains their readiness for schools, Zill and Resnick investigated, on whether early educational experiences promote school readiness. Love and Raikes focused on the five dimensions, physical and motor development, social and emotional development, learning, language and cognitive development and three supporting conditions which were, the children's participation in high quality preschool programs, socialization by parents as the first teachers, and receipt of adequate nutrition and health care. Zill and Resnick, on the contrary focused on the potential benefits that older preschool children may derive from participation in early childhood education programs. Earlier, in turn focused on the period of time during which children make the transition from preschool to grade school, and it was argued that there are a number of factors that operate during this interval, that is, before, during and after the transition has taken place, which may promote or impede children's school readiness. Early found that practices based in schools or performed by teachers and parents are intended to facilitate children's transition into grade school. From his survey, Early noted that services that are designed to prepare children for successful school transitions are rare and are seldom based on sound developmental principles or practices. It was also noted that it is important to devise a pretransition practices that encourage children to form and maintain relationships with people who can foster readiness and assist children before, during and after their transition to school. Findings from the studies have brought to light how children's school readiness can contribute to a smooth transition to formal schooling. Transition practices from both ends has not been considered in any of the studies mentioned by Ladd (2005) whose focus was from what the children know, what they can do, but it is interesting to note that what the children know and what they can do, not only depends on parents but on teachers from both ends.

\section{METHODS}

The research design used in this study is a qualitative one as it explored the understandings and practices of teachers who prepare children to leave preschool and enter primary school. The study adopted the epistemology of constructionist, with an interpretive perspective, as a philosophical stance which is consistent with constructionism. Qualitative case study research is the approach chosen for this qualitative inquiry.

Purposeful sampling was used to select participants. Using purposeful sampling, sending and receiving teachers working in a public school with a pre-primary unit attached, a preschool teacher who works with preschool leavers in a private preschool, a primary teacher who works with Standard I children who come from different milieus to a primary school was ideal for the study. In-depth interview was conducted with participants from the 
purposive sampling. Minichiello, Aroni, Timewell and Alexander (1995) argue that, this style of interviewing allows researchers to use both a structured approach, as well as a more 'conversational' style, in order to answer the research questions. Although, the interview was based on specific guiding questions, it was conducted in a more conversational manner, in order to establish rapport with the participant and make the teachers feel comfortable.

\section{FINDINGS}

The preschool teachers claimed that the children know everything they need to know before leaving preschool to go to primary school while the primary school teachers stated that they have to start anew with the children when they join Std I. Preschool teachers use the National Curriculum Framework of Pre-Primary and children learn informally through areas of learning such as Personal, Social and Emotional Development (PSED), Mathematical and Logical Thinking (MLT), Communication Language and Literacy (CLL), Body and Environmental Awareness (BEA), Expressive, Creative and Aesthetic Development (ECAD) and Health and Physical Development (HPD), while in primary schools teachers use the National Curriculum Framework of Primary and children learn formally through various subjects such as, Mathematics, English, French, Science \& Geography and Health. Preschool teachers use activity sheets while primary school teachers prepare lesson plans on a daily basis. Preschool teachers use mostly the play based approach and the integrated approach while primary school teachers do not use any particular approach to teach children in their classrooms. By the end of preschool year, the preschool teachers believe that the 5 year olds know everything that they have been taught and that they are ready to go to primary school. However, when the same children reach primary school, the teacher noted that they did not know anything. While preschool teachers said that they prepare children to join primary school by telling them about what they should and should not do in the primary classroom, yet, primary school teachers said that they still need to set rules in the classroom because children who join Standard I walk around, talk to their friends and teachers anytime, they are not very independent and do not show much respect to the adults at school. At preschool, children are taught to color, draw, and later copy words. Primary school teachers noticed that children who join Standard I do not know how to write or even hold a pencil. This study has also revealed that primary school teachers have certain expectations for children who join Standard I. The primary school teachers believe that children should know the alphabets, numbers from 1 to 10 ; basic shapes, colors, and most importantly, they should know how to communicate properly. Preschool teachers do all that the primary school teachers expect from the children using the performance indicators and descriptors in the NCF PP while preparing activities for the children when they are in preschool. Primary school teachers also compared preschool teachers to the parents of children. They explained that when children join primary school, some parents tell them to take care of children just like the preschool teacher did, or the parents would tell them that they need to be very loving and caring towards the child, that they should not shout or yell at the child. Eventually, parents of the children who join Standard I tend to be more worried and create some kind of anxiety in the child. As one primary school teacher pointed out, when the parents tell the child not to cry, when the child was not crying, the latter starts crying as soon as he or she has been asked not to cry. Parents should participate and be involved in the education of their child, but on the first day of primary school, parents should encourage children to be strong, motivated and determined to attend same. Primary school teachers said that children are welcomed for half a day on the first day and children are given coloring activity, they are taken for a 
walk around the school premises for a school visit, they are given refreshments and they engage in a lot of conversation about Christmas, holidays, their likes and dislikes. It is on the second day that the class teacher will talk to the children on her own as on the first day there are other teachers from other classes who come to help to welcome children who join Standard I. Preschool teachers see to it that all the objectives in the NCF PP are met before children leave preschool, while the primary school teachers are not at all aware of what and how children learn in preschool. All they know is that in preschool there is informal learning while when the children join Standard I it is their first formal schooling.

\section{CONCLUSIONS}

The preschool teachers seem to be doing what they are supposed to do. They are confident about what they do and how they do it at preschool. However the expectations of the primary school teachers are not met when the children join Standard I. In preschool, children are being cared for by a mother figure, but in Standard I children are expected to be more independent and show more autonomy. Primary school teachers explained that it is quite difficult to pay more attention to any particular child in a classroom as there are around 28 children in one class and the teacher is alone with them. One of the participants has explained that initially there was the Bridging the Gap Initiative, which was very helpful to ease transition of children from preschool to primary school, but it has been quite some time now that the Bridging the Gap has been removed from the education system. From both ends, teachers are doing their level best to support the transition of children from preschool to primary school. The question still arises on how making the transition of children effortless when they join Standard I. Children leave preschool by November and join primary schools around the $10^{\text {th }}$ of January. Do children forget everything during the period that they do not attend preschool? Do children not know anything, when they join Standard I or are they scared to show that, they know? These questions arise and are unanswered, after having studied the transition practices of teachers from both ends. The Developmental Learner Profile, which is a document that has been launched in January 2016 are presently in the preschools. Primary school teachers, who will work with Grade I, as from January 2017 will receive a document, which will show the abilities, competencies, and skills a child has achieved at preschool. The primary school teachers believe that, the document may help if they get it early. They also believe that, if there was some communication between themselves and the preschool educators prior to the children leaving the preschool it may help them understand what goes on in the preschool and how to bring along the continuity, until the children adapt to the formal setting of primary schools.

\section{REFERENCES}

1. Arnold, C., Bartlett, K., Gowani, S., \& Merali, R. (2006). Is every-body ready? Readiness, transition and continuity. Reflec-tions and moving forward. Paper commissioned for the EFAGlobal Monitoring Report 2007, Strong Foundations: EarlyChildhood Care and Education. Retrieved September 16, 2008, from http://unesdoc.unesco.org/images/0014/001474/14744le.pdf.

2. Arnold, C., Bartlett, K., Gowani, S., \& Merali, R. (2007). Is every-body ready? Readiness, transition and continuity: Reflec-tions and moving forward. Working Paper 41. The Hague,Netherlands: Bernard van Leer Foundation.

3. Athola, A., Silinskas, G., Poikonen, P., Kontoniemi, M., Niemi, P. \& Nurmi, J. (2010). Transition to formal schooling: 
Do transition practices matter for academic performance?. Early Childhood Research Quarterly 26 (3) 295-302. Retrieved from http://www. sciencedirect.com/science/article/pii/S088520061000092X

4. Beach, K. (1999). Consequential Transitions: A Sociocultural Expedition Beyong Transfer in Education. Review of Research in Education, 24, 101-139.

5. Brooker, L. (2002) Starting School: Young Children Learning Culture, Buckingham; Open University Press.

6. Brooker, L. (2008) Supporting Transitions in the Early years, London: McGraw-Hill.

7. Broström, S., \& Wagner, J. T. (Eds.). (2003). Early childhood education in five Nordic countries: Perspectives on the transition from preschool to school.

8. Broström, S. (2002) 'Communication and continuity in the transition from kindergarten to school', in H. Fabian and A. W. Dunlop (eds.) Transitions in the Early Years: Debating Continuity and Progression for Children in Early Education, London: Routledge Flamer.

9. Campbell Clark, S. (2000) 'Work/family border theory: A new theory of work/family balance, Human Relations 53(6): $747-770$.

10. Cassidy, M. (2010). “They Do It Anyway”: A study of primary 1 Teachers' perceptions of children's transition into primary education. Early Years: An International Journal of Research and Development, 25(2), 143 - 153.

11. Cole, M. (1996). Cultural Psychology: A once and future discipline. Cambridge, MA: Harvard University Press.

12. Copple, C., \& Bredekamp, S. (2009). Developmentally appropriate practice in early childhood programs. Washing, DC: National Association for the Education of Young Children.

13. Cox, M. LaParo, K. \& Pianta, R. (2000) Teachers' reported transition practices for children transitioning into kindergarten and first grade. Exceptional Children, 67(1), 7-20.

14. Dockett, S., \& Perry, B. (2004). What makes a successful transition to school? Views of Australian parents and teachers. International Journal of Early Years Education, 12(3), 217 - 230.

15. Dockett, S., \& Perry, B. (2013, in press). Trends and tensions: Australian and international research about starting school. International Journal of Early Years Education.

16. Dockett, S., Petriwskj, A., \& Perry, B. (2014). Theorising Transition: Shifts and Tensions. In Transitions to School International Reserach, Policy and Practice (Vol. 9, pp. 1-2). Springer. doi:10.1007/978-94-007-7350-9_1.

17. Dodge, D., Colker, L. J., \& Heroman, C. (2002). The Creative Curriculum Developmental Continuum Assessment System. Washington, DC: Teaching Strategies.

18. Dunlop, A. W. (2002) Early Years Educational Transitions: Study for Stirling Council, Glasgow: University of Strathclyde/Stirling Council.

19. Dunlop, A. W., \& Fabian, H. (2007). Informing transitions in the early years: Research, policy and practice. Maidenhead: Open University Press/McGraw-Hill.

20. Fabian, H. (2007). Informing transitions. In A.-W. Dunlop \& H. Fabian (Eds.), Informing transitions in the early years (pp. 3 - 17). Maidenhead: Open University Press/McGraw-Hill.

21. Fabian, H., \& Dunlop, A. W. (2007). Outcomes of Good Practice in Transition Processes for Children Entering 
Primary School. Working Papers in Early Childhood Development, No. 42. Bernard van Leer Foundation. PO Box 82334, 2508 EH, The Hague, The Netherlands.

22. Fabian, H. (2013). Towards Successful Transitions. In K. Margetts and A. Kienig, International Perspectives on Transition to School - Reconceptualising beliefs, policy and practice (pp. 45 - 55). Routledge.

23. Fthenakis, W. E. (1998). Family transitions and quality in early childhood education. European Early Childhood Education Research Journal, 6(1), 5 - 17.

24. Griebel, W., \& Nielsen, R. (2009). A developmental psychology perspective in Germany: Co-construction of transitions between family and education systems by the child, parents and pedagogues. Early Years, 29(1), 59 - 68.

25. Hirst, M., Jervis, N., Visagie, K., Sojo, V., \& Cavanagh, S. (2011). Transition to primary school: A review of the literature, Canberra: Commonwealth of Australia.

26. Johannson, I. (2007) 'Horizontal transitions: What can it mean for children in the early school years?', in A. -W. Dunloop and H. Fabian (eds.) Informing Transitions in the Early Years (pp. 33 - 44), Berkshire: Open University Press

27. Kienig, A., (2013) Children's Transition from Kindergarten to Primary school. In K. M. Kienig, International Perspectives on Transition to School - Reconceptualising beliefs, policy and practice (pp. 22 - 30). Routledge.

28. Kotaman, H. (2009). Okul öncesi eğitimde High Scopemodeli [High Scope model in early childhood education]. Pamukkale Üniversitesi Eğitim Fakültesi Dergisi [PamukkaleUniversity Journal of Education], 26, 31-41.

29. Kraft-Sayre, M. E., \& Pianta, R. C. (2000). Enhancing the Transition to Kindergarten: Linking Children, Families, \& Schools. Baltimore: Paul Publishing Co.

30. LaParo, K. M., Kraft-Sayre, M., \& Pianta, R. C. (2003). Preschool to kindergartentransition activities: Involvement and satisfaction of families and teachers. Journal of Research in Childhood Education, 17(2), 147-158.

31. Li, H. C. W., Mak, Y. W., Chan, S. S., Chu, A. K., Lee, E. Y., \& Lam, T. H. (2013). Effectiveness of a play-integrated primary one preparatory programme to enhance a smooth transition for children. Journal of health psychology. 18(1) 10-25. Doi: 1359105311434052.

32. LoCasale-Crouch, J., Mashburn, A. J., Downer, J. T., \& Pianta,R. C. (2008). Pre-kindergarten teachers' use of transitionpractices and children's adjustment to kindergarten. EarlyChildhood Research Quarterly, 23, 124-139.

33. Mascareño, M., Doolaard, S., \& Bosker, R. J. (2014). Profiles of Child Developmental Dimensions in Kindergarten and the Prediction of Achievement in the First and Second Grades of Primary School. Early Education and Development, 25(5), 703-722.

34. McCormick, K., Mullins, B. and Townley, K., (2005). Transition in Early Childhood, Frankfort, KY: Kentucky Department of Education.

35. Minichiello, VA., Aroni, R., Timewell, E., \& Alexander, L., (1995). In-d(Beach, 1999)epth Interviewing: Principles, Techniques and Analysis (Second ed.). Melbourne, Australia: Longman.

36. Nutbrown, C. (1994) Threads of Thinking. London: Paul Chapman Publishing.

37. O'Kane, M. (2007a) 'Building bridges: The Transition from preschool to primary school for children in Ireland', 
Unpublished PhD Thesis, Dublin Institute of Technology.

38. O'Kane, M. (2009) 'The transition from preschool to primary school in Ireland: Views of primary school teachers', in INTO (2009) INTO Consultative Conference on Education 2008, Transitions in the Primary School, Final Report, Dublin: INTO

39. Page, J. M. (2000). Reframing the early childhood curriculum: Educational imperatives for the future. London: Routledge/Falmer.

40. Petriwskj, A., Thorpe, K., \& Tayler, C. (2005). Trends in construction of transition to school in three western regions, 1990 - 2004. International Journal of Early Years Education, 13(1), 55 - 69.

41. Perry, B., Dockett, S., \& Petriwskyj, A. (2014). Transitions to School - International Research, Policy and Practice. Springer Netherlands.

42. Pianta, R. C., \& Kraft-Sayre, M. (2003). Successful kindergarten transition: Yourguide to connecting children, families, and schools. Baltimore, MD: Paul H. Brookes.

43. Pianta, R. C., Rimm-Kaufman, S. E., \& Cox, M. J. (1999). Introduction. Anecological approach to kindergarten transition. In R. C. Pianta \& M. J. Cox(Eds.), The transition to kindergarten (pp.3-12). Baltimore, MD: Paul H. Brookes

44. Ramey, C. T., \& Ramey, S. L. (1999). Beginning school for children at risk. In R. C. Pianta \& M. J. Cox (Eds.), The transition to Kindergarten (pp. 217 - 251). Baltimore: Paul Brookes.

45. Rimm-Kaufman, S. E., \& Pianta, R. C. (2000). An ecological perspectiveon the transition to kindergarten: A theoretical frameworkto guide empirical research. Journal of Applied DevelopmentalPsychology, 21, 491-511.

46. Rimm-Kaufman, S. E., Pianta, R. C., \& Cox, M. J. (2000).Teachers' judgments of problems in the transition tokindergarten. Early Childhood Research Quarterly, 15(2),147-166.

47. Rodrigues, A. (2000). Final report on the evaluation of the project "Effecting a smooth transition from nursery to primary." Report to UNICEF Guyana.

48. Rosenkoetter, S., Schroeder, C., Rous, B., Hains, A., Shaw, J., \& McCormick, K. (2009). A review of research in early childhood transition: Child and family studies. Technical Report \#5. Lexington: University of Kentucky, Human Development Institute, National Early Childhood Transition Centre. Available at http://www.ihdi.uky.edu/nectcl.

49. Schulting, A. B., Malone, P. S., \& Dodge, K. A. (2005). The effect of school-based kindergarten transition policies and practices on child academic outcomes. Developmental Psychology, 41(6), 860-871.

50. Suzuki, M. (2013) Japanese Children's Transition between Two Worlds: Mapping How Kindergarten and ElementarySchool Teachers Think about Children and their Activities. (Doctoral Dissertation). Retrieved from ProQuest (Accessed on December 2013).

51. United Nations Children's Fund (UNICEF), (2012). School Readiness: A conceptual framework.

52. http://www.unicef.org/education/files/Chil2Child_ConceptualFramework_FINAL\%281\%29.PDF. Accessed 8 Dec 2013.

53. Vrinioti, K., Einarsdóttir, J., \& Broström, S. (2010). Transitions from preschool to primary school (pp. 16 - 20). In H. 
Müller (Ed.) Transition from preschool to school: Emphasising literacy. Comments and reflection by researchers from eight European Countries. Cologne: EU - Agency, Regional Government of Cologne/Germany.

54. Yeboah, D. A. (2002). Enhancing transition from early childhood phase to primary education: Evidence from the research literature. Early Years, 11(1), 51 - 68. 